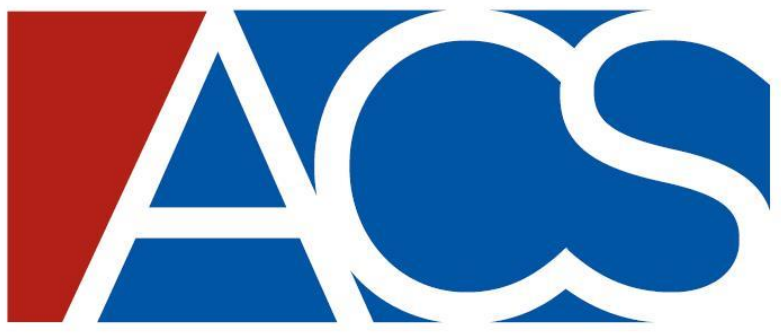

Issue Brief

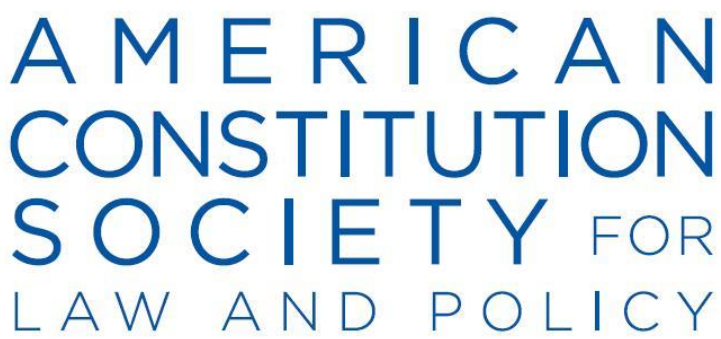

November 2015

\title{
Friedrichs v. California Teachers Association: The American Labor Relations System in Jeopardy
}

\section{Ann C. Hodges}

The petitioners in Friedrichs v. California Teachers Association seek to overturn longstanding law relating to union security in the public sector. A decision in favor of the petitioners will invalidate provisions in thousands of collective bargaining agreements covering millions of workers. Additionally, it has the potential to upend the labor relations system in the United States. To understand how this might be the case, this Issue Brief will review the history of union security and the Supreme Court decisions that upheld union security agreements in the public sector. The Issue Brief will then look at the Friedrichs case itself, engaging in an analysis of the case which concludes that the Court should reach the same result as in prior cases.

\section{The History of Union Security}

\section{A. The Private Sector}

Union security, a method of using agreements with employers to insure that those represented by unions provide support for that representation, has a long history in the United States beginning in the private sector. When the National Labor Relations Act (NLRA) was passed in 1935, it did not bar employer agreements to hire only union members. ${ }^{1}$ In 1947, Congress added a provision that barred these "closed shop" agreements but allowed the "union shop," an agreement that required employees to join the union within 30 days of hire as a condition of employment. Under a union shop agreement, the "membership" was considered only a "financial core" membership, because an employee could only be lawfully terminated for failure to pay dues and fees. The 1947 amendments

\footnotetext{
${ }^{1}$ For a summary of the evolution of the law in the private sector, see KENNETH G. DAU-SCHMIDT ET AL., LABOR LAW IN THE CONTEMPORARY WORKPLACE 1038-46 (2d ed. 2014); Kenneth G. Dau-Schmidt, Union Security Agreements Under the National Labor Relations Act: The Statute, the Constitution, and the Court's Opinion in Beck, 27 HARV. J. ON LEGIS. 51, 57-63 (1990).
} 
to the NLRA also permitted states to pass so-called "right-to-work" laws, ${ }^{2}$ which barred union security agreements in the state. ${ }^{3}$

Subsequently, the Supreme Court interpreted both the Railway Labor Act and the National Labor Relations Act to permit only union security agreements that required payment for collective bargaining and contract administration, but not for political and ideological activities. ${ }^{4}$ Interpreting the statutes in this way avoided the constitutional question of whether requiring objecting employees to join the union or pay for political and ideological activities violated the First Amendment. ${ }^{5}$ The National Labor Relations Board (NLRB) has formulated rules for union procedures to insure that objectors are provided with the necessary information on how to opt out of payment of full dues and how to challenge the union's allocation of expenses among chargeable expenses, those related to the union's representational duties, and nonchargeable expenses, which are all others. ${ }^{6}$

\section{B. The Public Sector}

While widespread unionization in the public sector came later than in the private sector, most states adopted labor relations laws similar to the NLRA in dealing with public sector employees. ${ }^{7}$ Many of these laws, like the NLRA, permit unions to negotiate what are known as "fair share" agreements with employers, allowing unions to charge employees for the cost of collective bargaining and contract administration. Like the private sector provisions, these laws have come

\footnotetext{
2 "Right-to-work" laws prohibit union security agreements in the states that enact them. The term "right-to-work" is misleading at best as the laws have no bearing on an individual's right to employment. I use the terminology because it has become dominant and widely recognized.

3 Historically, right-to-work laws predominated in the south. Analysts of the prevalence of right-to-work laws in the south have concluded that they reflect a culture which prioritizes individualism over collectivism and resistance to national government. In addition, historically, campaigns for right-to-work legislation emphasized preserving existing racial order. See Raymond L. Hogler, The Persistent Effects of Slavery in the United States: Culture, Legal Policy, and the Decline of American Labor Unions, in THE DisUnited STATES OF AMERICA: EMPLOYMENT RELATIONS SySTEMS IN CONFLICT 19, 30 (David Jacobs, et al. eds., 2014).

${ }^{4}$ See Railway Emp. Dept. v. Hanson, 351 U.S. 225, 238 (1956) ("We only hold that the requirement for financial support of the collective-bargaining agency by all who receive the benefits of its work is within the power of Congress under the Commerce Clause and does not violate either the First or the Fifth Amendments. We express no opinion on the use of other conditions to secure or maintain membership in a labor organization operating under a union or closed shop agreement."); Int'l Ass'n of Machinists v. Street, 367 U.S. 740, 749 (1961) (“Clearly we passed neither upon forced association in any other aspect nor upon the issue of the use of exacted money for political causes which were opposed by the employment," construing the law to require only payment for representational activities to avoid the constitutional question); Commc'ns Workers of Am. v. Beck, 487 U.S. 735, 761-62 (1988) (declining to decide whether there was state action but interpreting the NLRA's union security provisions consistent with those of the Railway Labor Act). There is significant doubt, however, about whether state action is involved in the negotiation of a union security agreement in the private sector and thus whether the Court was truly avoiding a constitutional question in these decisions. See Dau-Schmidt, Union Security Agreements, supra note 1, at 66, 70, 111-40.

5 Street, 367 U.S. at 749; Beck, 487 U.S. at 761-62.

${ }^{6}$ NLRB, Employer/Union Rights and Obligations: What Are the Rules About Union Dues?, https://www.nlrb.gov/rights-weprotect/employerunion-rights-and-obligations.

7 See Joseph Slater, The Assault on Public Sector Collective Bargaining: Real Harms and Imaginary Benefits, AM. CONST. SOC'Y FOR LAW AND POL'Y 2 (June 2011), available at http://www.acslaw.org/sites/default/files/Slater_Collective_Bargaining.pdf.
}

Friedrichs v. California Teachers Association: The American Labor Relations System in Jeopardy| 2 
under repeated constitutional challenge. ${ }^{8}$ In 1977, the Supreme Court held in Abood v. Detroit Board of Education that charging objectors for collective bargaining and contract administration was consistent with the First Amendment, but charging for political or other activities was not. ${ }^{9}$ Subsequent challenges led the Court to require specific procedures allowing objectors to opt out of paying full dues and to challenge the union's categorization of expenses. ${ }^{10}$ The Court further mandated that unions provide notice to objectors of chargeable expenses, as well as an audit of those expenses, which would facilitate any challenge to the unions' determination of chargeable expenses. ${ }^{11}$

\section{The Rationale for Allowing Union Security Agreements}

The United States, unlike most developed countries, has adopted a system of exclusive representation in both the private and public sectors. ${ }^{12}$ The exclusive representation system provides that when a majority of employees in a bargaining group select a union representative, that union represents all of the workers regardless of their individual desires. The majority rule is similar to our political system and indeed, the analogy has been regularly applied by courts and commentators analyzing our system. ${ }^{13}$ This system benefits the employer and the chosen union, although not necessarily unions as a group. The employer negotiates with one union and administers one uniform contract for the group. Enforcement of the contract is handled by the union, almost exclusively through an internal grievance and arbitration procedure either negotiated by the parties, or in some states required by law. As a corollary to the exclusive representation system, the union is required to represent all of the workers fairly and without discrimination, regardless of their membership status or support of the union. This duty of fair representation is legally enforceable; employees not fairly represented can bring legal action against the union. ${ }^{14} \mathrm{~A}$ third element of the system is the requirement that employees pay for the fair representation that the union is required to provide. This is the fair share fee or financial core membership requirement. The exception to this rule is the inability of unions to charge nonmembers in states that pass rightto-work laws.

\footnotetext{
8 The relentless challenges to union finances are funded by several employer-financed organizations, most notably the National Right to Work Legal Defense Foundation, not by individual employees. See DAU-SCHMIDT ET AL., supra note 1, at 1055; NAT'L RigHT TO WORK LEGAL DEF. FOUND., www.nrtw.org/en/about (last visited Oct. 20, 2015).

9 Abood v. Detroit Board of Education, 431 U.S. 209, 209-10 (1977).

${ }^{10}$ Chi. Teachers Union Local No. 1 v. Hudson, 475 U.S. 292, 310 (1986).

${ }^{11}$ Hudson, 475 U.S. at 306-07.

12 Martin H. Malin et al., Public Sector Employment: Cases and Materials 340 (2d ed. 2011).

13 See, e.g, Steele v. Louisville \& Nashville Railroad, 323 U.S. 192, 202 (1944) ("Congress has seen fit to clothe the bargaining representative with powers comparable to those possessed by a legislative body both to create and restrict the rights of those whom it represents ... .”); United Steelworkers of Am. v. Warrior \& Gulf Nav. Co., 363 U.S. 574,580 (1960) (“A collective bargaining agreement is an effort to erect a system of industrial self-government.”); Vaca v. Sipes, 386 U.S. 171, 182 (1967) ("The collective bargaining system as encouraged by Congress and administered by the NLRB of necessity subordinates the interests of an individual employee to the collective interests of all employees in a bargaining unit.”).

${ }^{14}$ See Vaca, 386 U.S. at 186-87.
}

Friedrichs v. California Teachers Association: The American Labor Relations System in Jeopardy| 3 
Fair share fees are necessary because of the collective action problem that results from some employees obtaining benefits without payment. ${ }^{15}$ In such a situation, there is every incentive for even those who support the union to withdraw financial support. Where no one is compelled to pay for a public good, the rational actor will allow others to pay. This is the theory behind payment of taxes in a civil society - the entire community benefits from roads, police and fire protection. Thus, all should pay though each individual may well pay for roads and protection that he or she never uses. Eventually, without mandatory payment for public goods, there is a risk that the entire system will collapse. ${ }^{16}$

The labor relations system was adopted to provide a peaceful method of resolving labor disputes. Congress, in the case of the private sector and federal employment, and the states, for state and local government employees, determined that a system that provided for union representation and collective bargaining when chosen by the employees offered the best option for providing employee voice in the workplace. Employee voice provides benefits to employers, including improved morale and productivity, and information about how to best use employer resources to provide targeted employee benefits and compensation to retain productive workers. Without such information, employers may expend resources without stemming employee dissatisfaction. Further, widespread labor unrest preceded enactment of the NLRA, and in the public sector, research indicates that creating a system of labor relations and dispute resolution reduces the number and duration of strikes. ${ }^{17}$ Courts in both the private and public sectors have recognized these rationales as justification for mandatory fees to support mandatory union representation. ${ }^{18}$

The Abood Court recognized that requiring employees to support their collective bargaining representative impacted their First Amendment interests as they might disagree with some or all of the union's activities, even those directly involved in collective bargaining. ${ }^{19}$ This is particularly true in the public sector, where the government is the employer and the First Amendment is directly implicated. But the Court also recognized that the exclusive representation system imposed "great responsibilities" on the union requiring substantial expenditures on behalf of all employees. ${ }^{20}$ Thus,

15 See generally Mancur Olson, The Logic of Collective Action: Public Goods and the Theory of Groups 66-97 (1971).

$16 I d$. at 88 (indicating that rational workers who choose not to pay for what they can obtain for free will result in the demise of unions).

17 See Janet Currie \& Sheena McConnell, The Impact of Collective-Bargaining Legislation on Disputes in the U.S. Public Sector: No Legislation May Be the Worst Legislation, 37 J.L. \& Econ. 519, 519, 530, 542 (1994) (finding that the costs of labor disputes are highest where there is no framework for bargaining or dispute resolution, including more frequent and longer strikes).

18 Abood, 431 U.S. at 224 ("The desirability of labor peace is no less important in the public sector, nor is the risk of 'free riders' any smaller.”); Beck, 487 U.S. at 755 (“[S]uch agreements promot[e] stability”, quoting S. Rep. No. 105, 80"th Cong., $1^{\text {st }}$ Sess. 6 (1947)); Hanson, 351 U.S. at 233 ("Industrial peace along the arteries of commerce is a legitimate objective; and Congress has great latitude in choosing the methods by which it is to be obtained."); Street, 367 U.S. at 812 ("Congress legislated to correct what it found to be abuses in the domain of promoting industrial peace.")

19 Abood, 431 U.S. at 235.

${ }^{20}$ Id. at 221 .

Friedrichs v. California Teachers Association: The American Labor Relations System in Jeopardy| 4 
it held that fair share provisions were necessary to avoid the collective action problem and to effectuate the labor relations system adopted by the state of Michigan. ${ }^{21}$

The Court's subsequent decision in Lehnert v. Ferris Faculty Association established that expenses that could be charged to objectors were those "(1) . . 'germane' to collective-bargaining activity; (2) ... justified by the government's vital policy interest in labor peace and avoiding 'free riders'; and (3) not significantly add[ing] to the burdening of free speech that is inherent in the allowance of an agency or union shop." 22 In that case, the Court found that lobbying expenses and other political activities, except those related to ratification or implementation of the collective bargaining agreement, were not chargeable to dissenting employees. ${ }^{23}$ The Court noted that "[i]ndividual employees are free to petition their neighbors and government in opposition to the union which represents them in the workplace."24

\section{The Current Case: Friedrichs in Context}

\section{A. The Expedited Path to the Supreme Court}

It is the long-settled law described above that the petitioners in Friedrichs seek to overturn. Their arguments, however, are the same as those rejected by the Court in these earlier cases. Two recent opinions in union security cases authored by Justice Alito, which questioned the decisions in earlier cases, brought this case to the Court. In Knoxv. SEIU Local 1000, the issues before the Court were (1) whether a union had to provide additional notice to bargaining unit employees when it implemented a special assessment to finance opposition to several ballot measures in California; and (2) whether the assessment was chargeable to dissenters. ${ }^{25}$ The union charged a reduced portion of the additional assessment to those who had already indicated a desire not to pay for expenses other than those germane to the union's representation, but offered no additional opportunity for new dissenters. Pontificating far beyond the scope of the questions on which certiorari was granted, Justice Alito attacked the constitutionality of fair share fees and held that for special assessments or dues increases, the union not only had to issue a second notice to bargaining unit employees, but also no charges could be assessed to any employee who did not choose to pay the increase. ${ }^{26}$ Accordingly, Justice Alito and the majority imposed an opt-in regime for special assessments, contrary to the opt-out provisions for regular fair share fees. This newly adopted regime presumes that employees choose not to pay and requires them to take affirmative action to pay, rather than requiring affirmative action by those who choose not to pay.

Justice Alito's next opportunity to address the issue came in 2014 in Harris v. Quinn. ${ }^{27}$ There the question was the constitutionality of fair share fees for home care providers who were employed by

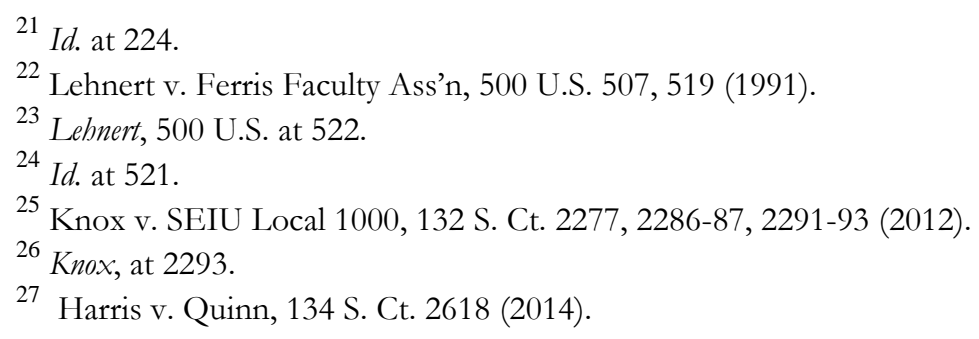

Friedrichs v. California Teachers Association: The American Labor Relations System in Jeopardy| 5 
both individuals for whom they provided care and the state, which paid their salaries and provided some benefits. In Harris, Justice Alito extensively critiqued Abood before holding that fair share fees were not chargeable to employees who were not exclusively employed by the state. ${ }^{28}$ To the majority, the rationales supporting fair share fees did not apply when the union's bargaining was limited to those terms and conditions of employment controlled by the state. ${ }^{29}$ Despite the arguments of the Harris petitioners and Justice Alito's criticism of Abood, the Court in Harris did not overrule Abood.

In light of Justice Alito's opinions, however, the Friedrichs petitioners, deciding to strike while the iron was hot, asked the lower courts for judgment on the pleadings in their case challenging the constitutionality of fair share fees in the public sector. ${ }^{30}$ While the defendants argued that a record was essential to decide the case, the petitioners were determined to get their case to the Supreme Court as quickly as possible, expecting that at least some current justices would be likely to vote to overturn Abood. Accordingly, the posture of the case before the Court is one where only the pleadings are at issue and the Court must accept the respondents' (the nonmovant's) pleadings as true. $^{31}$

\section{B. The Issues Before the Court}

\section{The Weight of Stare Decisis}

The first issue that the petitioners must overcome is the doctrine of stare decisis, which weighs against overruling existing precedent absent persuasive justification. ${ }^{32}$ The reliance interests that would be adversely affected by overruling Abood include the laws of more than 20 states, and thousands of collective bargaining agreements governing millions of employees. ${ }^{33}$ Abood has been the foundation not only of numerous cases involving union fees, but of other cases involving mandatory fees, such as state bar dues and university student fees, that would be cast into doubt by a decision overturning it. ${ }^{34}$ In light of these interests, it would take a very strong showing to warrant rejecting Abood. As the next section will demonstrate, however, Abood considered all of the arguments that the petitioners and Justice Alito make and determined that any infringement on First Amendment rights was justified by the government's interest in stable labor relations. Nothing has changed since that decision but the Court and its perception of labor unions. If anything, the case

28 Harris. at 2638.

29 Id. at 2641.

${ }^{30}$ Friedrichs v. Cal. Teachers Ass'n, No. SACV 13-676-JLS, 2013 WL 9825479, at*2 n.3 (C.D. Cal., Dec. 5, 2013) ("Plaintiffs' ultimate aim-and thus their request for judgment on the pleadings in favor of Defendants-is to have these precedents overturned on appeal.”); Friedrichs v. Cal. Teachers Ass'n, No. 13-57095, 2014 WL 10076847, at *1 (9th Cir., Nov. 18, 2014).

${ }^{31}$ Friedrichs v. Cal. Teachers Ass'n, No. SACV 13-676-JLS, 2013 WL 9825479, at*2.

${ }^{32}$ Harris, 134 S. Ct. at 2645 (Kagan, J., dissenting).

${ }^{33} I d$. at 2652.

${ }^{34}$ Id. (citing Keller v. State Bar of Cal., 110 S. Ct. 2228 (1990) (state bar fees)); Bd. of Regents of Univ. of Wis. Sys. v. Southworth, 120 S. Ct. 1346 (2000) (public university student fees); Glickman v. Wileman Bros. \& Elliott, Inc., 117 S. Ct. 2130 (1997) (commercial advertising assessments).

Friedrichs v. California Teachers Association: The American Labor Relations System in Jeopardy| 6 
for the government is even stronger because of subsequent Court decisions strengthening the government's hand when it deals with its own employees.

\section{Abood Redux: The Players Have Changed but the Arguments Remain the Same}

The primary argument of the petitioners is that collective bargaining in the public sector is inherently political because it involves government spending. Thus, they argue, requiring them to pay any money to the union is compelling political speech in violation of their First Amendment rights. Having made that argument, the petitioners then claim that the justifications of labor peace and avoiding collective action problems do not warrant the infringement on speech. Only, they suggest, if free-riding would bankrupt the union would charging objectors be justified. ${ }^{35}$

Justice Alito argued in Harris that Abood failed to recognize the political character of public sector collective bargaining. ${ }^{36}$ Nothing could be further from the truth. The Abood petitioners made the same argument, and while the Court recognized that at least some of the decisions of public employers in bargaining are political, it held that this did not require that public sector employees be treated differently than private sector employees in matters of union security, stating:

There can be no quarrel with the truism that because public employee unions attempt to influence governmental policymaking, their activities and the views of members who disagree with them may be properly termed political. But that characterization does not raise the ideas and beliefs of public employees onto a higher plane than the ideas and beliefs of private employees. ${ }^{37}$

Indeed, as the Court pointed out, private sector employees may have objections to the expenditure of union fees but have fewer ways than their public sector counterparts to express their disagreement. Public sector employees even have the right to attend public meetings to oppose directly the positions advocated by their exclusive bargaining representative in collective bargaining. ${ }^{38}$

Further, since Abood, the Court has repeatedly found that the government has far greater latitude in dealing with its employees than other citizens. ${ }^{39}$ The First Amendment interests of public employees often must yield to the employer's interests in managing its workforce. ${ }^{40}$ Indeed, the Court has cautioned against constitutionalizing employment disputes. In Connick v. Myers, the Court found that Myers had no constitutional claim when disciplined for her speech about confidence and

\footnotetext{
35 See Brief for Petitioner, Friedrichs v. Cal. Teachers Ass'n, cert. granted, 135 S.Ct. 2933 (2015) (No. 14-915), 2015 WL 5261564.

${ }^{36}$ Harris, 134 S. Ct. at 2621.

37 Abood, 431 U.S. at 231.

38 Madison Sch. Dist. v. Wis. Emp. Rel. Comm'n, 429 U.S. 167, 175-176 (1976). Cf. Emporium Capwell v. W. Addition Cmty. Org., 420 U.S. 50 (1975) (upholding as lawful termination of private sector employees who bypassed their union in an effort to deal directly with their employer although their efforts were not inconsistent with union positions.)

39 See, e.g., Engquist v. Or. Dep't. of Agric., 553 U.S. 591, 599 (2008)

40 See, e.g., Garcetti v. Ceballos, 547 U.S. 410 (2006).
}

Friedrichs v. California Teachers Association: The American Labor Relations System in Jeopardy| 7 
trust in supervision, office morale and the need for a grievance procedure. ${ }^{41}$ These were not matters of public concern, according to the Court. Similarly, in Borough of Duryea v. Guarnieri, the Court held that a police chief who alleged that he was retaliated against for filing union grievances and a lawsuit relating to his discharge and denial of overtime, among other complaints, did not have a constitutional claim under the petitions clause for the same reason. ${ }^{42}$ Thus, the Court's own precedents suggest that public employee speech and petitions relating to issues subject to collective bargaining do not warrant strong protection under the First Amendment, not because the issues may not be considered political in a broad sense, but because they are not of sufficient public concern to warrant interference with the government's right to manage its employees.

These limitations on the First Amendment rights of public employees derive from the needs of the government as employer. As the Court stated in Borough of Duryea:

[A] citizen who accepts public employment "must accept certain limitations on his or her freedom." Garcetti v. Ceballos, 547 U.S. 410, 418, 126 S.Ct. 1951, 164 L.Ed.2d 689 (2006). The government has a substantial interest in ensuring that all of its operations are efficient and effective. That interest may require broad authority to supervise the conduct of public employees. ${ }^{43}$

This "broad authority" to choose how to manage the workforce should include the authority to adopt a long accepted system of labor relations that includes the elements of exclusive representation, mandatory union representation of all employees and correspondingly, the requirement to pay for that representation. Any limited burden on First Amendment rights caused by the need to insure that unions have sufficient resources to effectively participate in the system is outweighed by the benefits of effective and efficient management of employees and government services that result. Examples abound of government employers and unions working together to reduce government expenditures, improve productivity, improve teacher quality, and improve student achievement, adding weight to the value of the existing system of labor relations. ${ }^{44}$

Justice Alito in Harris argued that collective bargaining implicates constitutional concerns where individual grievances do not because more government spending is at stake. ${ }^{45}$ At bottom, this seems to be a challenge to governmental decisions to adopt any regime of bargaining. The claim was properly debunked by Justice Kagan:

And nowhere has the Court ever suggested, as the majority does today, . . . that if a certain dollar amount is at stake (but how much, exactly?), the constitutional treatment of an employee's expression becomes any different.

\footnotetext{
${ }^{41}$ Connick v. Myers, 461 U.S. 138, 148 (1983).

42 Borough of Duryea, Pa. v. Guarnieri, 131 S.Ct. 2488, 2491-92 (2011).

43 Duryea, 131 S.Ct. at 2494.

${ }^{44}$ David Lewin, et al., Getting it Right: Empirical Evidence and Policy Implications from Research on Public-Sector Unionism and Collective Bargaining 16-21 (2011).

${ }^{45}$ Harris, 134 S. Ct. at 2632-33, 2642-43.
}

Friedrichs v. California Teachers Association: The American Labor Relations System in Jeopardy| 8 
Consider an analogy, not involving union fees: Suppose an employee violates a government employer's work rules by demanding, at various inopportune times and places, higher wages for both himself and his co-workers (which, of course, will drive up public spending). The government employer disciplines the employee, and he brings a First Amendment claim. Would the Court consider his speech a matter of public concern under Pickering? I cannot believe it would, and indeed the petitioners' own counsel joins me in that view...

I can see no reason to treat the expressive interests of workers objecting to payment of union fees, like the petitioners here, as worthy of greater consideration. The subject matter of the speech is the same: wages and benefits for public employees. Or to put the point more fully: In both cases (mine and the real one), the employer is sanctioning employees for choosing either to say or not to say something respecting their terms and conditions of employment. Of course, in my hypothetical, the employer is stopping the employee from speaking, whereas in this or any other case involving union fees, the employer is forcing the employee to support such expression. But ... the "difference between compelled speech and compelled silence" is "without constitutional significance."

A related argument of the Friedrichs petitioners, mirroring a concern raised by Justice Alito in Harris, ${ }^{47}$ is that it has proved more difficult than Abood anticipated to distinguish between chargeable and nonchargeable expenditures. ${ }^{48}$ But again, Abood recognized that precise distinctions might be difficult. ${ }^{49}$ While there have been challenges to the allocation of expenses, these have been resolved by the courts based on the formula adopted by the Supreme Court in Lehnert. ${ }^{50}$ The existence of these challenges, financed by the same organizations that fund virtually all of the legal challenges to fair share, cannot be used to support a claim that line-drawing is difficult. A legal standard has been developed and consistently applied and followed to deal with such claims. Litigation has now clearly categorized most major expenditures of unions, resolving the issues with relatively clear lines between categories. That the powerful and well-funded opponents of unions continue to litigate every conceivable challenge does not demonstrate that the issues are more difficult than first thought.

Another argument set forth by the Friedrichs petitioners is that the interests in labor peace and avoiding free riders do not justify fair share fees. ${ }^{51}$ The Abood Court addressed this issue as well, recognizing that "the desirability of labor peace is no less important in the public sector, nor is the

\footnotetext{
${ }^{46} I d$. at 2655-56 (Kagan, J., dissenting) (quoting Riley v. Nat'l Fed'n of Blind of N.C., Inc., 487 U.S. 781,796 (1988)).

${ }^{4}$ Id. at 2631-32.

${ }^{48}$ Brief for Petitioner, supra note 35 , at *56-57.

49 Abood, 431 U.S. at 236 ("There will, of course, be difficult problems in drawing lines between collective-bargaining activities... and ideological activities unrelated to collective bargaining....”).

${ }^{50}$ Lehnert, 500 U.S. at 519.

${ }^{51}$ Brief for Petitioner, supra note 35 , at *30-44.
}

Friedrichs v. California Teachers Association: The American Labor Relations System in Jeopardy| 9 
risk of "free riders' any smaller." 52 The Court further recognized the "great responsibilities" of the exclusive representative, which involve the "expenditure of much time and money." 53 It is not only Abood, but also subsequent decisions such as Justice Scalia's concurrence in Lebnert that acknowledged the importance of avoiding free riders to the achievement of peaceful labor relations. ${ }^{54}$ As explained above, fair share fees are an essential element of the labor relations system that cannot be viewed in isolation. While a state would be free to adopt a different system such as Tennessee has done, ${ }^{55}$ as the Abood Court recognized, the adoption of exclusive representation carries with it the obligation to represent all employees. ${ }^{56}$ With that comes the collective action problem described above. And while the petitioners suggest that unions have voluntarily chosen this obligation, ${ }^{57}$ under the existing system, the employer can only bargain with the majority representative. ${ }^{58}$ Thus, the union that wants to represent employees must use the existing bargaining system adopted by the employer with its accompanying obligations.

It has been argued that fair share is not essential to exclusive representation systems because right-to-work laws bar fair share in some states and the system has survived. ${ }^{59}$ Additionally, some point to the federal system, which does not have fair share but has active unions with substantial membership. ${ }^{60}$ Neither of these examples is predictive of what would happen if fair share was deemed unconstitutional. First, the federal system has some unique features that make its applicability outside that system unpredictable. ${ }^{1}$ Second, most local unions that provide direct representational services are part of larger national organizations that can deploy resources where needed. Without fair share, the resources of these national organizations would be diminished. Research indicates that right-to-work laws encourage free riding and reduce union organizing efforts, as well as the success of union organizing efforts. ${ }^{62}$ Additionally, right-to-work states generally have lower union membership rates and lower union representation rates than states with fair share, indicating the greater difficulty of union organizing in those states. ${ }^{63}$ Reduced resources lead to

52 Abood, 431 U.S. at 224.

53 Id. at 221.

${ }^{54}$ Lehnert, 500 U.S. at 521-22, 556 (Scalia, J., concurring).

55 See Professional Educators Collaborative Conferencing Act of 2011, TENN. CodE ANN. \49-5-601 (West 2011). The Tennessee system of "Collaborative Conferencing" does not provide for exclusive union representation. Rather, this system permits multiple parties, including non-union employees, to be involved in employment related negotiations with management. Id.

56 Abood, 431 U.S. at 224.

${ }^{57}$ Brief for Petitioner, supra note 35 , at *24-25.

${ }^{58}$ CAL. GOV. CODE \ 3506.5 (West 2012).

${ }^{59}$ Brief for Petitioner, supra note 40 , at $* 30-31$.

${ }^{60}$ Id. at 31.

${ }^{61}$ Samuel Estreicher, The Paradox of Federal Sector Labor Relations: Voluntary Unionism Without Collective Bargaining Over Wages and Employee Benefits, NYU SCHOOL OF LAW (Sept. 30, 2015), available at http:/ / ssrn.com/abstract=2663113.

${ }^{62}$ William L. Moore, The Determinants and Effects of Right-to-Work Laws: A Review of the Recent Literature, 19 J. LAB. RES. 445 , 464 (1998).

${ }^{63} I d$. (finding "accumulating evidence indicates that [right-to-work] laws reduce the long-run extent of unionization by 5 to 8 percent."). Membership and coverage data by state is available at Union Membership, Coverage, Density and Employment by State, 2014, UNION MEMBERSHIP AND COVERAGE DATABASE, http://www.unionstats.com/ (last visited Oct. 20,

Friedrichs v. California Teachers Association: The American Labor Relations System in Jeopardy| I0 
weaker unions, which could further discourage union membership. Thus the fact that the current system is working does not indicate what would happen if the current system was radically altered. Perhaps the relatively peaceful labor relations of recent years have lulled some into dismissing the possibility of significant disruption by employees deprived of a voice in the workplace, but history tells us that employees without a legal method of voicing their frustration will rise up. The success of the current system in achieving peaceful labor relations should not lead to its demise.

\section{Consider The First Amendment Rights of Unions and Their Members}

An additional argument for rejecting efforts to overrule Abood is the impact of the mandatory representation obligation without a corresponding duty to pay on the First Amendment rights of the union and its members. As Catherine Fisk and Margaux Poueymirou have persuasively argued, if requiring union represented employees to pay money for the service they receive is compelled speech, ${ }^{64}$ then forcing the union to represent these employees using the money of members is also compelling speech. ${ }^{65}$ Although the Abood Court did not address this issue, it did not need to do so as it upheld the fair share system. Any consideration of overruling Abood must recognize that the union and its members have free speech rights that are violated by abandoning fair share. In addition to forcing union subsidization of speech on behalf of nonmembers, the free riders limit the resources that the union has to expend on political activities on behalf of its members, further impairing the speech rights of unions and their members. ${ }^{66}$ As Fisk and Poueymirou urge, reaffirming Abood is a reasonable compromise in a situation with conflicting First Amendment rights at stake. ${ }^{67}$ It requires all to pay for the services provided and does not mandate payment for political activities. As noted above, payment of fair share fees in no way restrains the employees from expressing their own views on the issues.

\section{Opt-In v. Opt-Out}

The second substantive question at issue in Friedrichs is whether the Constitution requires unions to adopt an opt-in scheme for collection of fair share fees in which employees must actively choose to pay full union dues. The systems upheld in many prior cases, including $A b o o d$, incorporated optout provisions under which an employee pays the amount of full dues unless the employee opts out after receiving the legally required notice from the union. There is no evidence in Friedrichs suggesting that an opt-out approach imposes a burden on anyone. Indeed the petitioners admit that they have opted out regularly and the union's pleadings establish that it sends a notice of the right to opt-out as required by law and all that is required to opt out is to check a box and return a form to the union. ${ }^{68}$ Further, if as the petitioners allege, inertia will cause some individuals who object to the

2015). The coverage data show the number and percentage of employees covered by union contracts, which includes both members and nonmembers. Id.

${ }^{64}$ And Fisk and Poueymirou make a persuasive argument that it is not. See Catherine Fisk \& Margaux Poueymirou, Harris v. Quinn and the Contradictions of Compelled Speech, 48 LOY. L.A. L. REV. 439, 461-470 (2015).

${ }^{65} I d$. at 488 .

${ }^{66} \mathrm{Id}$.

${ }^{67}$ Id. at $490-91$.

${ }^{68}$ Brief of Respondents Cal. Teachers Ass'n, et al. in Opposition at *4, Friedrichs v. Cal. Teachers Ass'n, cert. granted, 135 S.Ct. 2933 (2015) (No. 14-915), 2015 WL 1518077.

Friedrichs v. California Teachers Association: The American Labor Relations System in Jeopardy| I I 
union's positions to fail to opt out, ${ }^{69}$ then an opt-in regime will compound the free rider problem, enhancing the justification for reaffirming Abood. $^{70}$

The only union fees case in which an opt-in requirement has been mandated is Knox, where the Court imposed an opt-in regime for a mid-year assessment designed primarily to combat ballot initiatives that the union opposed when the notice of the assessment provided no specific opportunity to opt out. ${ }^{71}$ The situation was atypical, but the Court created the opt-in without the urging of either party. ${ }^{72}$ Justice Alito went so far as to suggest that the opt-out regime was unconstitutional generally, ${ }^{73}$ inviting the instant challenge. But opt-out has been approved in cases that compel speech far more directly than fair share fees, which constitute no more than payment for a service provided and accepted. For example in West Virginia State Board of Education v. Barnette, the Court found it constitutionally sufficient for First Amendment purposes that students could opt out of saluting the flag and saying the pledge of allegiance. ${ }^{74}$ And in Wooley v. Maynard, the Court held that individuals who objected to the message on New Hampshire's license plate could simply cover it with tape. ${ }^{75}$

The opt-out system for fair share fees has been repeatedly approved by the Court in a number of cases, albeit without deep specific analysis. Given the careful balancing of the labor relations system and considering the First Amendment rights of all involved, as well as the government's interests in regulating its work force, the Court should not reject it here, especially when there is simply no evidence of any burden on employees using opt-out.

\section{The Posture of the Case}

While most of this Issue Brief has concentrated on the merits of the issues, a case decided on the pleadings is a poor vehicle for reconsidering major constitutional precedent. Many of the petitioners' arguments rely on assumptions, not facts. For example, the petitioners suggest that free ridership is not a serious problem for unions and that they will continue to operate and effectively represent employees without fair share fees. ${ }^{76}$ But there is no such evidence in the record because there is no record. Petitioners even fault the union for not making such a showing. ${ }^{77}$ Yet petitioners' own actions insured that no factual record exists.

Similarly, there is no evidence that an opt-out regime leads to employees unwillingly subsidizing nonchargeable activities due to inertia or lack of attention. It may well be that an opt-in

\footnotetext{
69 Brief for Petitioner, supra note 40, at *11-14.

70 Catherine Fisk \& Erwin Chemerinsky, Political Speech and Associational Rights after Knox v. SEIU, Local 1000,98 CORNELL L. REV. 1023, 1068 (2013).

71 Knox, 132 S. Ct. at 2286. The union honored opt-out requests received for regular fees, but offered no new opportunity to opt out of the newly implemented assessment for employees who failed to opt out of regular fees. Id. 72 Id. at 2306 (Breyer, J., dissenting).

73 Id. at 2290

${ }^{74}$ Fisk \& Chemerinsky, supra note 70, at 1048-49 (citing W. Va. State Bd. of Educ. v. Barnette, 319 U.S. 624, 642(1943)).

75 Id. (citing Wooley v. Maynard, 430 U.S. 705, 713 (1977)).

76 Brief for Petitioner, supra note 40 , at $* 30-31$.

77 Id. at *31.
}

Friedrichs v. California Teachers Association: The American Labor Relations System in Jeopardy| 12 
regime burdens the First Amendment rights of the union and its members more than an opt-out regime burdens dissenters. However, without an evidentiary record, assumptions about this important question are all that is left. And assumptions, far more subject to the influence of bias than facts, are a poor basis on which to decide serious constitutional issues, particularly when longstanding precedent is at stake. ${ }^{78}$

\section{Concluding Thoughts on a Dangerous Case}

Because fair share is an integral part of the existing labor relations system, a decision by the Court holding it unconstitutional could disrupt the entire system and lead to unpredictable results. What we know from history, however, is that without an effective system to resolve labor disputes, the potential for legal and illegal strikes or other disruptive protest increases. The end of fair share will almost certainly weaken unions, although it is unlikely to completely destroy them. While some argue that unions might benefit from a regime that permits only voluntary support by becoming more active and responsive to members, ${ }^{79}$ there are enormous resource challenges for unions required to represent workers without a reliable source of funding.

Weaker unions will affect the balance of power in the workplace and society in general. Workers will have fewer vehicles for voice in the workplace. Laws may change in ways unfavorable to workers without powerful union support. Insurgent movements for higher minimum wages and paid leave may be less successful. Lower rates of unionization may exacerbate the already significant economic inequality in the United States. ${ }^{80}$

As the foregoing demonstrates, the rationale for upholding fair share is as strong or stronger today as it was in 1977. Fair share is a bedrock principle of the U.S. labor relations system. The Supreme Court correctly concluded in 1977 that the interests in peaceful and stable labor relations justified any infringement on the First Amendment rights of dissenters. Since that time, the Court has recognized that when acting as an employer, the government has even greater authority to restrict the First Amendment rights of its employees; that fair share fees are payable to a union does not change the calculus.

The Court should leave well enough alone.

\footnotetext{
${ }^{78}$ For further analysis of problems with the state of the record, see Catherine Fisk, Symposium: The Friedrichs Petition Should be Dismissed, SCOTUSBLOG (Aug. 26, 2015), http://www.scotusblog.com/2015/08/symposium-the-friedrichspetition-should-be-dismissed/.

${ }^{79}$ Michael Oswalt, The Grand Bargain: Revitalizing Labor Through NLRA Reform and Radical Workplace Relations, 57 DUKE L.J. 691, 723 (2007).

${ }^{80}$ Richard Freeman et al., How Does Declining Unionism Affect the American Middle Class and Intergenerational Mobility?, NAT'L BUREAU OF ECON. RES. (October 2015), available at www.nber.org/papers/w21638 (finding a strong relationship between unionization, upward mobility, and membership in the middle class).
}

Friedrichs v. California Teachers Association: The American Labor Relations System in Jeopardy| I 3 


\section{About the Author}

Ann Hodges is a Professor of Law at the University of Richmond School of Law, where she teaches and writes in the areas of labor and employment law, nonprofit organizations, and feminist legal theory. Professor Hodges is the co-author of West's Principles of Employment Law and West's Public Sector Employment: Cases and Materials and has written over two dozen articles, and numerous book chapters, on labor and employment related topics. Professor Hodges has served on the editorial board of the Employee Rights and Employment Policy Journal since 1996. She has been a member of the Labor Law Group, an invitation-only nonprofit organization for scholars and practitioners dedicated to producing high-quality materials to prepare students to practice labor and employment law, since 2007, and has served on its Editorial Committee since 2011. She is a frequent speaker at national symposiums on employment and labor law, and has made numerous presentations to academics, practitioners, nonprofit organizations, health care professionals, and cancer patients and their families. She is co-founder of the Legal Information Network for Cancer (LINC), a nonprofit organization that assists cancer patients and their families with the business side of cancer. Professor Hodges received the University of Richmond's Distinguished Educator Award in 1995 and again in 2009, and received the Black Law Students Association's Willie L. Moore Award in 2006. She earned her J.D. from the Northwestern University School of Law and her M.A. in labor and industrial relations from the University of Illinois.

\section{Acknowledgement}

This Issue Brief was completed with the research assistance of Christopher Ryan Dodson, Class of 2016, University of Richmond School of Law.

\section{About the American Constitution Society for Law and Policy}

The American Constitution Society (ACS) believes that law should be a force to improve the lives of all people. ACS works for positive change by shaping debate on vitally important legal and constitutional issues through development and promotion of high-impact ideas to opinion leaders and the media; by building networks of lawyers, law students, judges and policymakers dedicated to those ideas; and by countering the activist conservative legal movement that has sought to erode our enduring constitutional values. By bringing together powerful, relevant ideas and passionate, talented people, ACS makes a difference in the constitutional, legal and public policy debates that shape our democracy. 